\title{
Potret Cyberbullying Siswa Kelas VIII SMPN 2 Temanggung Tahun Pelajaran 2019/2020
}

\author{
Herdiyanto ${ }^{1}$,Sugiyo ${ }^{2}$, Moh Jafar $^{3}$ \\ Pascasarjana UNNES \\ E-mail: jasun050664@gmail.com
}

\begin{abstract}
Penelitin ini bertujuan untuk mengetahui gambaran cyberbullying siswa kelas VIII SMPN 2 Temanggung. Metode penelitian yang dipakai adalah kuantitatif desain penelitian kuantitatif deskriptif. Sampel penelitian ini memakai 192 siswa kelas VII SMP Negeri 2 Temanggung Tahun Palajaran 2019/2020. Instrumen yang digunakan dalam penelitian ini adalah skala cyberbullying hasil pengembangan dari Teori Cyberbullying menurut Nancy Willard. Analisis data dilakukan dengan dua cara, yaitu: analisis kuantitatif deskiptif dan uji t. Hasil dari analisis skala cyberbullying menunjukkan sebanyak 111 siswa berkategori rendah, 76 siswa berkategori sedang, dan sebanyak 5 siswa berkategori tinggi. Hasil uji t dengan Man Witney menunjukkan nilai signifikansi $(0,019)<0,05$. Rata-rata skor cyberbullying siswa laki-laki $(108,14)$ lebih besar daripada siswa perempuan $(88,87)$. Kesimpulannya di SMPN 2 Temanggung tingkat cyberbullying bervariasi. Siswa laki-laki memiliki kecenderungan melakukan cyberbullying daripada siswa perempuan. Berdasarkan hasil penelitian, guru BK dapat memberikan tindak lanjut berupa layanan dasar kepada siswa yang memiliki tingkat cyberbullying rendah dan layanan responsif kepada siswa yang memiliki tingkat cyberbullying kategori sedang ataupun tinggi. Adapun bagi peneliti selanjutnya, data hasil penelitian dapat digunakan sebagai studi pendahuluan untuk menentukan intervensi yang tepat. Peneliti selanjutnya, dapat menyesuaikan intervensi dengan karakteristik dan tingkat cyberbullying siswa
\end{abstract}

Keywords: cyberbullying, smartphone, social media

\section{PENDAHULUAN}

Dunia saat ini memasuki era revolusi industri 4.0 yang baru-baru ini hangat dibahas mengenai era disrupsi. Era disrupsi membawa banyak inovasi yang secara holistik maupun parsial mengusik tatanan sistem yang konvensional. Antika dan Muslikah (2018) menjelaskan bahwa masyarakat Indonesia saat ini telah memasuki aliran era disrupsi yang dicirikan sebagai masa penuh gangguan dan terjadi banyak perubahan. Adanya kepesatan perkembangan ilmu pengetahuan dan teknologi (IPTEK) yang berdampak pada terjadinya perubahan dalam berbagai kehidupan menjadi ciri khas era disruptif. Tidak bisa dipungkiri, saat ini dunia tengah menyaksikan perubahan sosial dan budaya yang dikendalikan teknologi informasi (internet) melalui smartphone. 
Penggunaan smartphone akan membawa banyak manfaat jika pengguna bijak dalam memanfaatkannya, namun jugu sebaliknya. Seperti halnya yang disampaikan oleh Prabawa, A.F. (2018) bahwa salah satu indikator era disruptif yakni perkembangan IPTEK diibaratkan seperti dua sisi mata uang. Kedua sisi itu akan menjadi sebuah peluang ataupun tantangan, bergantung pada cara masyarakat dalam menyikapi. Peluang yang dapat kita lihat adalah remaja masa kini berkembang menjadi individu yang multi tasking, gandrung IPTEK, berfikir kritis, penuh percaya diri, dan memiliki jejaring pertemanan yang luas. Kontras dengan peluang, tantangan remaja saat ini adalah terbiasa hidup dalam atmosfer informasi yang tersedia dengan cepat sehingga memiliki kecenderungan berjiwa egosentris dan serba instan. Bila sisi negatif tidak disikapi dengan baik, maka akan membawa dampak yang merugikan.

Dampak negatif penggunaan smartphone memunculkan berbagai kasus seperti: kriminal, pelecehan, teroris, obesitas, sampai gangguan mental (dalam Detiknews, 2018; Liputan6, 2018). Kemunculan kasus-kasus tersebut seperti halnya rumput ilalang, satu diselesaikan tetapi muncul kasus baru. Salah satu usaha sadar yang dilakukan oleh kominfo untuk membatasi situs negatif sudah dilakukan sejak lama dengan program yang dikenal dengan Internet Positif (data Kominfo, 2014). Akan tetapi, saat ini telah muncul berbagai trend baru yang berkembang di kalangan pengguna internet, salah satunya adalah twitwar. Secara sederhana, twitwar dapat dimaknai sebagai "perang" antar pemilik akun sosial media. Bermula dari perbedaan pendapat yang berlanjut panjang, bahkan sampai berbumbu kata-kata yang melibatkan emosi. Fenomena twitwar menjadi salah satu bentuk intimidasi secara verbal melalui dunia maya, dan mengarah pada tindakan cyberbullying.

Cyberbullying dapat dimaknai sebagai tindakan intimidasi/perundungan yang dilakukan oleh perorangan atau kelompok kepada seseorang melalui sosial media (Slonje, R., \& Smith, P., 2008; Zalaquett, C. \& Chatters, S., 2014; Ferrara, dkk, 2018). Willard, N (2005), membagi indikator cyberbullying berdasarkan jenisnya menjadi 7, yaitu: 1) Flaming, mengirim pesan yang berbau marah, kasar, atau vulgar yang ditujukan kepada individu atau grup online. Contoh: Berkata kotor di grup; 2) HarassmentPelecehan, mengirim pesan yang menyerang kepada individu secara berulang-ulang-Perang Pesan. Contoh: Memberikan komen tidak suka di kolom komentar FB/IG; 3) Cyberstalking, pelecehan dengan ancaman bahaya atau sangat mengintimidasi. Contoh: melecehkan melalui gambar, melecehkan fisik, karakter; 4) Denigration, memposting pernyataan yang berbahaya, tidak benar atau kejam tentang orang lain. Contoh: Melakukan fitnah di medsos; 5) Masquerade, berpurapura menjadi orang lain dan mengirim materi sehingga menyebabkan orang itu terlihat buruk, atau mendapat masalah. Contoh: Akun palsu/ Nomor palsu/ anonym; 6) Outing and Trickery, mengiriman atau posting materi yang berisi informasi pribadi atau memalukan tentang seseorang, Meminta informasi yang memalukan untuk menyebarkan informasi tersebut ke publik, dan meneruskan informasi pribadi pesan dan gambar. Contoh: Meminta password email untuk membuka akun IG, hack akun; dan 7) Exclusive, mengacu pada tindakan yang secara sengaja mengecualikan seseorang dari grup online. Contoh: Mengeluarkan dari grup, mengabaikan dari grup.

Kasus cyberbullying saat ini menjadi perhatian khalayak luas baik di dalam atau luar negeri. Icellioglu, S. \& Ozden, M. (2013), mencatat 56\% dari 1.470 pengguna internet dengan usia rata-rata 23 tahun di Turki, diindikasikan menjadi korban cyberbullying setidaknya sekali dalam seumur hidup mereka. Lebih lanjut Akbulut, Y. \& Eristi, B. (2011) menambahkan bahwa kebanyakan cyberbullying terjadi pada lakilaki dengan kondisi yang berbeda-beda, baik secara usia, program studi, kemampuan bahasa, ataupun status ekonomi sosial. Campbell, M. (2005) mengatakan di Inggris satu dari empat anak-anak dilaporkan telah dirundung melalui telepon seluler atau di internet, sedangkan di Australia lebih dari 40 dari 120 siswa mengetahui seseorang 
telah dirundung menggunakan teknologi. Kasus serupa ditemukan di Amerika, 15\% dari sampel teridentifikasi sebagai pelaku cyberbullying dan $7 \%$ pernah menjadi korban cyberbullying (Ybarra, M. \& Mitchell, K., 2004).

Fenomena cyberbullying juga mencuat di Indonesia, beberapa penelitian menunjukkan berbagai kasus cyberbullying terjadi di kalangan siswa. Hasil penelitian di kalangan siswa SMP dan SMA di kota Magelang, Yogyakarta, dan Semarang menunjukkan sebanyak 28\% dari 363 siswa mengalami cyberbullying. Sedangkan, di Aceh bentuk cyberbullying tertinggi yang dilakukan oleh remaja perempuan SMA adalah outing and trickery dan exclusion. Adapun media yang sering digunakan untuk melakukan aksi bullying adalah Instagram, Path, Facebook, dan yang paling sering adalah Twitter (Rahayu, F., 2012; Putri, F., 2016; Rachmatan, R. \& Ayunizar, S., 2017). Siswa SMP di Bekasi menjadi salah satu pelaku cyberbullying karena kurangnya pengawasan orangtua dan sekolah. Bahkan di Surakarta ada seorang korban dan sekaligus pelaku cyberbullying (Prasadana, D., 2017; Shofy, dkk., 2017).

Selain munculnya cyberbullying yang secara sporadis, dampak akibat dari cyberbullying juga peru diperhatikan. Dampak dari cyberbullying sangat berbahaya bagi kesejahteraan jiwa seorang individu. Cyberbullying meningkatkan resiko anakanak untuk putus sekolah, bunuh diri, pembunuhan, dan tindakan kekerasan lainnya (Erb, T., 2008). Kasus bunuh diri Yoga Cahyadi yang terjadi di Yogyakarta akibat dibully atas gagalnya festival musik menjadi salah satu bukti bahayanya dampak cyberbullying (Natalia, E., 2016). Hinduja S. \& Patchin, J. W. (2010) juga mengemukakan bahwa korban cyberbullying mengalami depresi, kesedihan, kemarahan, frustrasi, dan malu.

Fenomena yang sama juga ditemukan di SMP Negeri 2 Temanggung. Hasil wawancara dengan tiga orang guru BK diketahui beberapa siswa mengalami cyberbullying melalui media online, seperti twitter, whatsapp, facebook dan lainnya. Rata-rata kasus tersebut terungkap melalui inisiatif siswa untuk melapor ke guru BK dan melalui pengembangan kasus. Pengembangan kasus dilakukan sebab sebagian besar siswa yang menjadi korban merasa ketakutan untuk melapor kepada guru BK sebab diancam oleh pelaku. Selian itu, ada juga siswa yang ketika berada di kelas selalu murung ternyata dia juga korban bully dari teman-teman sekelasnya.

Merujuk dari fenomena tersebut, penting bagi guru BK untuk segera memberikan layanan yang dapat membantu korban dan menyadarkan pelaku cyberbullying. Melalui instrumentasi pengumpulan data guru BK dapat mengetahui gambaran tingkat cyberbullying dan menentukan skala prioritas siswa yang memerlukan layanan. Maka, tujuan dari penelitian ini adalah untuk mengetahui gambaran cyberbullying siswa yang nantinya akan bermanfaat bagi guru BK dalam memberikan layanan yang tepat guna.

\section{METODE}

Penelitian ini menggunakan pendekatan penelitian kuantitatif dengan desain penelitian kuantitatif deskriptif. Tujuan dari penelitian ini untuk mengetahui profil tingkat cyberbullying siswa dan mengetahui apakah ada perbedaan tingkat cyberbulllying ditinjau dari jenis kelamin. Sampel penelitian ini memakai 192 siswa kelas VIII SMP Negeri 2 Temanggung Tahun Palajaran 2019/2020. Instrumen yang digunakan dalam penelitian ini adalah skala cyberbullying hasil pengembangan dari Teori Cyberbullying menurut Nancy Willard. Instrumen yang telah dikembangkan dilakukan uji ahli BK dan Uji validitas serta uji reliabilitas. Instrumen yang telah dinyatakan lolos uji terdiri dari 30 item pernyataan dengan rentang skor 1-4 (selalu sampai tidak pernah). Instrumen diberikan kepada 192 siswa untuk memperoleh data 
yang selanjutnya dilakukan analisis. Analisis data dilakukan dengan dua cara, yaitu analisis kuantitatif deskiptif dan uji t. Analisis kuantitatid deskriptif dilakukan untuk mengetahui persentasi gambaran cyberbullying siswa. Uji t digunakan untuk mengetahui ada tidaknya perbedaan cyberbullying pada siswa laki-laki dan perempuan.

\section{HASIL DAN PEMBAHASAN}

Hasil dari analisis skala cyberbullying yang dihimpun dari 192 siswa diketahui tingkat cyberbullying yang bervariasi. Hasil analisis menunjukkan sebanyak 111 siswa atau 58\% tergolong dalam kategori rendah, 76 siswa atau 39\% tergolong dalam kategori sedang, dan sebanyak 5 siswa atau 3\% termasuk dalam kategori tinggi. Berdasar data yang telah dihimpun tersebut ditemukan rata-rata tingkat cyberbullying siswa kelas VIII SMPN 2 Temanggung adalah 64 dengan kategori sedang. Hasil analisis berupa tingkat cyberbullying secara rinci dijelaskan dalam tabel 1.

Kondisi sampel yang memiliki tingkat cyberbullying bervariasi merupakan hasil dari faktor internal ataupun eksternal. Kondisi emosional, frustrasi, dendam, ataupun kecemasan merupakan pemicu adanya tindak cyberbullying. Kuranganya pengawasan orangtua dalam menggunakan media sosial, kondisi psikologis dari korban, situasi yang mendukung potensi besar akan terjadinya cyberbullying. Demikian halnya dengan Alim, S. (2016) menjelaskan bahwa faktor yang memicu timbulnya cyberbullying ada 2 hal, yakni: faktor demografis dan faktor psikologis. Faktor demografis berkaitan dengan pemilihan teman sebaya, jenjang usia, jenis kelamin, tingkat pendidikan, status ekonomi-sosial, dan etnis. Faktor psikologis yang dimaksud meliputi: harga diri, depresi, empati, kecanduan internet, serta citra diri. Kowalski, dkk. (2014) merangkum faktor yang menyebabkan cyberbullying menjadi dua, yaitu: faktor pribadi dan faktor situasional. Faktor pribadi yang menjadi memicu di antaranya: usia lebih dewasa daripada korban, motif balas dendam, empati dengan temannya, status ekonomi yang tinggi, dan juga terpengaruh alkohol. Faktor situasional yang dimaksud di antaranya terprovokasi oleh oranglain, pengawasan dari orangtua kurang akan penggunaan medsos, dan kondisi lingkungan yang memicu frustrasi. Sehingga dapat diambil sebuah kesimpulan bahwa kondisi internal ataupun eksternal memiliki pengaruh terhadap tingkat cyberbullying siswa. Semakin kompleks kondisi yang dialami siswa maka semakin bervariasi tingkat cyberbullying.

Berdasar pada hasil analisis, setiap kategori memiliki indikator yang berbeda-beda. Adapun indikator tingkat cyberbullying disesuaikan dengan konsep Nancy Willard. Siswa yang termasuk kategori tinggi memiliki ciri-ciri, yaitu: melakukan tindakan intimidasi berupa melecehkan, mengancam, dan membuat tidak nyaman oranglain yang dilakukan secara perseorangan atau kelompok melalui media sosial whatsapp dan mengajak oranglain melakukan hal yang sama. Siswa dengan kategori sedang memiliki ciri, siswa melakukan tindakan intimidasi berupa melecehkan, mengancam, dan membuat tidak nyaman oranglain yang dilakukan secara perseorangan atau kelompok melalui media sosial whatsapp tanpa mengajak oranglain melakukan hal yang sama. Siswa yang masuk dalam kategori rendah dicirikan, siswa bertindak baik dan tidak melakukan intimidasi secara perseorangan atau kelompok melalui media sosial whatsapp. 
Tabel 1. Tingkat Cyberbullying Siswa SMPN 2 Temanggung

\begin{tabular}{llcc}
\hline Kategori & Skor & Jumlah & Persentase \\
\hline Kategori Tinggi & $91-120$ & 5 & $3 \%$ \\
\hline Kategori Sedang & $61-90$ & 76 & $39 \%$ \\
\hline Kategori Rendah & $30-60$ & 111 & $58 \%$ \\
\hline Total & & 192 & $100 \%$ \\
\hline M & & \multicolumn{2}{c}{64} \\
SD & & 54 \\
\hline
\end{tabular}

Selain dari variasi tingkat cyberbullying, jenis cyberbullying yang dilakukan oleh siswa juga bermacam jenis. Willard mengatakan jenis cyberbullying ada 7 , yaitu: 1) Flaming; 2) Harassment/Pelecehan; 3) Cyberstalking; 4) Denigration; 5) Masquerade; 6) Outing and Trickery; dan 7) Exclusive. Berdasarkan hasil analisis data sebanyak yang telah dihimpun dari 193 siswa ditemukan jenis cyberbullying yang populer dilakukan siswa. Berikut paparan data rata-rata jenis cyberbullying yang dilakukan siswa dapat dilihat pada tabel 2.

\section{Tabel 2. Jenis Cyberbullying Siswa SMPN 2 Temanggung}

\begin{tabular}{lrr}
\hline \multicolumn{1}{c}{ Jenis Cyberbullying } & Rata-rata & Persentase \\
\hline Denigration & 381,0 & 17,7 \\
\hline Outing and Trickery & 333,3 & 15,5 \\
\hline Exclusive & 330,0 & 15,3 \\
\hline Flaming & 300,5 & 14,0 \\
\hline Harassment & 294,5 & 13,7 \\
\hline Cyberstalking & 259,4 & 12,1 \\
\hline Masquerade & 253,8 & 11,8 \\
\hline Total & 2152,5 & 100 \\
\hline
\end{tabular}

Dari hasil paparan data tersebut diketahui bahwa jenis cyberbullying yang populer dilakukan siswa kelas VIII adalah Denigration. Menurut Willard, N (2005) Denigration merupakan kegiatan memposting pernyataan yang berbahaya, tidak benar atau kejam tentang orang lain. Contoh: Melakukan fitnah di medsos. Denigration dapat diartikan sebagai bentuk sindiran yang dengan sengaja dilakukan oleh pelaku cyberbullying pada halaman posting media sosial atau status media sosial. Banyak faktor yang dapat memicu terjadinya denigration, misalnya: rasa dendam, iseng, mencari bahan untuk populer, mencari dukungan dari orang yang sefrequensi. Denigration menjadi populer dilakukan pada kalangan remaja sebab cara melakukannya dapat dilakukan tanpa perlu berkontak langsung dengan korban. Berbeda dengan flaming, harassment, exclusive atau trickery yang masih melakukan kontak dengan oranglain, seperti: berbalas pesan yang menyerang, mengelabuhi korban, atu mengeluarkan korban dari sebuah grup media sosial. Kontras dengan denigration, pelaku dapat melakukan denigration cukup dengan memposting informasi yang negatif atau mencemarkan nama baik korban di media sosial. Denigration dinilai sebagai bentuk cybebrullying yang memiliki efek kecil terhadap kondisi psikologis pelaku. Berbeda dengan bullying pada umumnya, pelaku akan 
secara langsung melihat kondisi perubahan psikologis dan emosi. Peneliti sebelumnya menganalogikan dengan kondisi tentara pasca Perang Dunia II dan Perang Vietnam. Tentara yang secara langsung bergerak didaratan akan jauh merasa bersalah, stres, trauma ketika teringat telah membunuh banyak musuh. Namun berbeda dengan pilot pesawat pembawa bom atom, dapat membunuh lebih banyak orang dalam skop keluarga, desa ataupun kota tanapa harus kontak langsung dengan target. Dengan demikian, kondisi pskologis pilot jauh lebih terkendali daripada tentara yang bergerak di darat (Lorenz, 1974; De Laender, 1996; Heirman, W \& Walrave, M., 2008). Seperti halnya denigration, pelaku melakukan berbagai sindiran melalui postingan media sosial tanpa melibatkan kontak langsung dengan korbannya sehingga pelaku merasa tenang-tenang saja atas apa yang diperbuat.

Selain dari hasil kajian data kuantitatif deskriptif, juga dibahas mengenai hasil uji t. Uji t dilakukan untuk mengetahui adanya perbedaan tingkat cyberbullying berdasarkan jenis kelamin. Uji t dianalisis dengan menggunakan Man Witney sebab data tidak berdistribusi normal dapat dilihat pada tabel berikut.

Tabel 3. Hasil Uji Mann-Whitney

\begin{tabular}{lr}
\hline \multicolumn{2}{c}{ Test Statistics } \\
\hline & \multicolumn{1}{c}{ Cyberbullying $^{\mathrm{a}}$} \\
\hline Mann-Whitney U & 3523,000 \\
\hline Wilcoxon W & 10309,000 \\
\hline $\mathrm{Z}$ & $-2,352$ \\
\hline $\begin{array}{l}\text { Asymp. Sig. (2- } \\
\text { tailed) }\end{array}$ &, 019 \\
\hline \multicolumn{2}{l}{ a. Grouping Variable: JK } \\
\hline
\end{tabular}

Hasil uji t dalam tabel 3. menunjukkan bahwa nilai Signifikansi $(0,019)<0,05$ yang dapat diartikan $\mathrm{HO}$ ditolak. Hipotesis awal adalah tidak ada perbedaan tingkat cyberbullying berdasarkan jenis kelamin. Sehingga dapat diambil kesimpulan bahwa terdapat perbedaan tingkat cyberbullying berdasarkan jenis kelamin yang dapat dilihat pada tabel 4 berikut ini.

Tabel 4. Rata-Rata Skor Cyberbullying berdasar Jenis Kelamin

\begin{tabular}{llrrr}
\hline \multicolumn{5}{c}{ Ranks } \\
& JK & N & Mean Rank & Sum of Ranks \\
\hline \multirow{3}{*}{ Cyberbullying } & Laki-Laki & 76 & $\mathbf{1 0 8 , 1 4}$ & 8219,00 \\
\cline { 2 - 5 } & Perempuan & 116 & $\mathbf{8 8 , 8 7}$ & 10309,00 \\
\cline { 2 - 5 } & Total & 192 & & \\
\hline
\end{tabular}

Pada tabel 4. ditujukkan bahwa rata-rata skor cyberbullying siswa laki-laki sebesar 108, 14 dan siswa perempuan sebesar 88,87. Kesimpulannya adalah siswa laki-laki memiliki kecenderungan melakukan cyberbullying daripada siswi perempuan.

Kondisi perbedaan tingkat cyberbullying antara siswa laki-laki dan perempuan dapat disebabkan oleh kemampuan kelola emosi. Hasmarlin, H. \& Hirmaningsih (2019) menguatkan bahwa regulasi emosi siswa laki-laki dan perempuan berbeda. Regulasi emosi siswa laki-laki lebih ekspresif dibanding dengan perempuan. Perbedaan ini dipengaruhi oleh perbedaan dalam expressive suppression dan tuntutan sosial budaya yang dianut. Ratnasari dan Suleeman (2017) menguatkan bahwa 
regulasi emosi antara laki-laki dan perempuan sangat erat kaitannya dengan perbedaan dalam expressive suppression. Laki-laki cenderung memendam emosinya, sebaliknya perempuan memiliki keluwesan dalam menggungkapkan emosinya. Pada konteks Indonesia, laki-laki seperti bom waktu yang emosinya dapat meledak ketika sudah puncak, sedangkan perempuan dalam mengekspresikan emosinya lebih dapat diterima daripada laki-laki. Hal serupa diungkapkan oleh Simon dan Nath (2004) bahwa laki-laki dan perempuan berbeda dalam mengekspresikan emosi baik verbal maupun non verbal. Perempuan lebih mengekspresikan emosi untuk menjaga hubungan interpersonal serta membuat perempuan tampak lemah dan tidak berdaya. Sedangkan laki-laki lebih mengekspresikan marah dan bangga untuk mempertahankan dan menunjukkan dominasi. Sehingga, dalam konteks cyberbullying siswa laki-laki cenderung memiliki tingkat cyberbullying yang tinggi dibanding perempuan sebab memiliki perbedaan karakter dalam expressive suppression.

Selain dari faktor kelola emosi, perbedaan tingkat cyberbullying antara siswa laki-laki dan perempuan juga dipengaruhi oleh kemampuan kontrol diri. Hasil penelitian Rizki, B (2015) menunjukkan bahwa terdapat perbedaan tingkat cyberbullying antara siswa laki-laki dan perempuan yang salah satunya dipengaruhi oleh kontrol diri. Siswa laki-laki memiliki kecenderungan dalam melakukan cyberbullying dibanding dengan siswa perempuan. Dapat diambil makna bahwa kontrol diri perempuan lebih baik daripada laki-laki. Hal ini dikuatkan oleh Krisnowati (2017), menyatakan bahwa semakin rendah kontrol diri dan regulasi emosi pada siswa, maka tingkat perilaku cyberbullying pada siswa akan semakin tinggi. Kontrol diri merupakan kemampuan dalam menahan ataupun mengarahkan diri menuju hal positif ketika dihadapkan dengan situai/kondisi tertentu (Hofmann, dkk., 2012). Siswa yang memiliki kontrol diri yang bagus akan menekan peluang terjadinya perilaku menyimpang, seperti cyberbullying. Kontrol diri erat kaitannya dengan sikap individu dalam mengelola emosi ataupun dorongan dalam diri sehingga bijak dalam membuat keputusan dan mengambil tindakan yang efektif sesuai dengan nilai moral dan harapan sosial (de Ridder, dkk., 2011).

\section{SIMPULAN}

Fenomena cybebrullying yang terjadi di SMPN 2 Temanggung perlu menjadi perhatian. Beberapa siswa ditemukan pernah mengalami cyberbullying melalui media sosial, seperti: twitter, whatsapp, facebook dan lainnya. Hasil pendalaman kasus, sebagian besar siswa yang menjadi korban merasa ketakutan untuk melapor kepada guru BK sebab diancam oleh pelaku. Selian itu, ada juga siswa yang ketika berada di kelas selalu murung ternyata dia juga korban bully dari teman-teman sekelasnya.

Merujuk pada fenomena tersebut, seyogianya perlu ada layanan segera dalam membantu korban dan menyadarkan pelaku cyberbullying Melalui instrumentasi pengumpulan data guru BK dapat mengetahui gambaran tingkat cyberbullying dan menentukan skala prioritas siswa yang memerlukan layanan. Dari hasil penghimpunan data melalui skala cyberbullying kepada 192 siswa, sebanyak 111 berkategori rendah, 76 berkategori sedang, dan 5 sisa dalam kategori tinggi. Secara umum, dari keseluruhan siswa yang diteliti, rata-rata masuk dalam kategori sedang. Kondisi tingkat cyberbullying siswa yang bervariasi, disebabkan oleh faktor internal dan eksternal. Kondisi psikologis (emosi, kontrol diri, dendam atau frustrasi) dan minimnya pengawasan orangtua dalam menggunakan media sosial berpengaruh terhadap potensi terjadinya cyberbullying.

Jenis cyberbullying yang populer ditemukan di SMPN 2 Temanggung adalah denigration. Denigration adalah tindakan mempublikasikan berita negatif untuk mencemarkan nama baik. Denigration menjadi populer dilakukan dibanding jenis 
cyberbullying lain, seperti halnya flaming, harassment, exclusive atau trickery sebab pelaku dapat melancarkan aksinya tanpa perlu berkontak langsung dengan korban. Dengan demikian, denigration memiliki dampak yang kecil terhadap kondisi psikologis pelaku. Pelaku merasa tenang-tenang saja atas apa yang diperbuat sebab sindiran hanya dilakukan dengan postingan media sosial tanpa melibatkan kontak langsung dengan korbannya.

Hasil uji t menunjukkan bahwa nilai Signifikansi $(0,019)<0,05$. Hasil itu dapat disimpulkan bahwa siswa laki-laki memiliki kecenderungan melakukan cyberbullying daripada siswi perempuan. Perbedaan tersebut dipengaruhi oleh kemampuan dalam mengelola emosi dan kontrol diri. Siswa laki-laki cenderung memiliki tingkat cyberbullying yang tinggi dibanding perempuan karena dipengaruhi oleh expressive suppression. Perempuan cenderung memiliki kemampuan untuk mengekspresikan emosi yang lebih dapat diterima daripada laki-laki. Selain itu, tingkat cyberbullying antara siswa laki-laki dan perempuan yang berbeda juga dipengaruhi oleh kemampuan kontrol diri. Dari rata-rata tingkat cyberbullying, laki-laki sebesar 108, 14 dan siswa perempuan sebesar 88,87. Maka dapat ditarik makna bahwa kontrol diri perempuan lebih baik daripada laki-laki sehingga menyebabkan tingkat cybebullying laki-laki lebih tinggi daripada perempuan.

Berdasarkan hasil penelitian, guru BK dapat memberikan tindak lanjut berupa layanan dasar berupa psikoedukasi kepada siswa yang memiliki tingkat cyberbullying rendah dan layanan responsif berupa konseling kepada siswa yang memiliki tingkat cyberbullying kategori sedang ataupun tinggi. Adapun bagi peneliti selanjutnya, data hasil penelitian dapat digunakan sebagai studi pendahuluan untuk menentukan intervensi yang tepat. Peneliti dapat meenyesuaikan intervensi dengan karakteristik dan tingkat cyberbullying siswa.

\section{DAFTAR PUSTAKA}

Akbulut, Y. dan Eristi, B. (2011). Cyberbullying and victimisation among turkish university students. Australasian Journal of Educational Technology, 27 (7), 1155-1170. doi: 10.14742/ajet.910.

Alim, S. (2016). Cyberbullying in the world of teenagers and social media: a literature review. International Journal of Cyber Behavior, Psychology and Learning, 6 (2), 68-95. doi: 10.4018/IJCBPL.2016040105.

Antika, E. R. \& Muslikah. "Konseling Kreatif: Strategi Efektif Pelayanan BK di Era Disruptif". Artikel. Seminar Nasional dengan Tema Strategi Pelayanan Bimbingan dan Konseling di Era Disrupsi di Universitas PGRI Semarang. Semarang, 21 Juli 2018.

Campbell, M. (2005). Cyber bullying: an old problem in a new guise?. Australian Journal of Guidance and Counselling, 15 (1), 68-76. Retrieved from: https://eprints.qut.edu.au/1925/.

De Laender, J. (1996). Het hart van de duisternis: psychologie van de menselijke wreedheid. Leuven: Davidsfonds.

De Ridder, D.T., De Boer, B.J., Lugtig, P., Bakker, A.B., \& Van Hoof, E.A. (2011). Not doing bad things is not equivalent to doing the right thing: distinguish between 
inhibitory and initiatory self-control. Personality and Individual Differences, 50 (2011), 1006-1011. doi: 10.1016/j.paid.2011.01.015.

Detiknews. (2018). Pelajar ini didiagnosa kecanduan smartphone, ditangani ahli jiwa. Retrieved from: https://news.detik.com/berita-jawa-timur/d-3824306/2-pelajarini-didiagnosa-kecanduan-smartphone-ditangani-ahli-jiwa.

Erb, T. D. (2008). A case for strengthening school district jurisdiction to punish off campus incidents of cyberbullying. Arizona State Law Journal, 40(1), 257-286. Retrieved from: https://heinonline.org/HOL/LandingPage?handle=hein.journals/arzjl40\&div=12 \&id=\&page.

Ferrara, P., Lanniello, F., Villani, A., \& Corsello, G. (2018). Cyberbullying a modern from of bullying: let's talk about this health and social problem. Italian Journal of Pediatrics, 44 (14), 1-3. doi: 10.1186/s13052-018-0446-4.

Hasmarlin, H. \& Hirmaningsih. (2019). Regulasi emosi pada remaja laki-laki dan perempuan. Marwah: Jurnal Perempuan, Agama dan Jender, 18(1), 87-95.

Heirman, W., \& Walrave, M. (2008). Assessing concerns and issues about the mediation of technology in cyberbullying. Cyberpsychology: Journal of Psychosocial Research on Cyberspace, 2(2), Retrieved from https://cyberpsychology.eu/article/view/4214/3256.

Hinduja, S. \& Patchin, J. W. (2010). Bullying, Cyberbullying, and Suicide. Archives of Suicide Research, 14 (1), 206-221. doi: 10.1080/13811118.2010.494133.

Hofmann, W., Baumeister, R.F., Förster, G., \& Vohs, K.D. (2012). Everyday Temptations: an experience sampling study of desire, conflict, and self-control. Journal of Personality and Social Psychology, 102 (6), 1318-1335. doi:10.1037/a0026545

Icellioglu, S. \& Ozden, M. (2013). Cyberbullying: a new kind of peer bullying through online technology and its relationship with aggression and social anxiety. Procedia-Social and Behavioral Sciences, 2014 (116), 4241-4245. doi: 10.1016/j.sbspro.2014.01.924.

Kominfo. (2014). Siaran pers no. 17 PIH kominfo tentang riset kominfo dan unicef menegenai perilaku anak dan remaja dalam menggunakan internet. Retrieved from: https://kominfo.go.id/index.php/content/detail/3834/Siaran+Pers+No.+17PIH-KOMINFO-2-

2014+tentang+Riset+Kominfo+dan+UNICEF+Mengenai+Perilaku+Anak+dan+ Remaja+Dalam+Menggunakan+Internet+/0/siaran_pers.

Kowalski, R. M., Giumetti, G. W., Schroeder, A. N., \& Lattanner, M. R. (2014). Bullying in the digital age: a critical review and meta-analysis of cyberbullying research among youth. Psychological Bulletin, 140 (4), 1073-1137. doi: 10.1037/a0035618.

Krisnowati. (2017). Pengaruh kontrol diri dan regulasi emosi terhadap perilaku 
cyberbullying pada siswa kelas $x$ smk negeri 9 semarang. Skripsi. Semarang: UNNES.

Liputan6. (2018). Wajib tahu, ini dampak buruk smartphone ke tubuh dan otak. Retrieved from: https://www.liputan6.com/tekno/read/3593233/wajib-tahu-inidampak-buruk-smartphone-ke-tubuh-dan-

otak?related=dable\&utm_expid=.9Z4i5ypGQeGiS7w9arwTvQ.1\&utm_referrer= https $\% 3 \mathrm{~A} \% 2 \mathrm{~F} \% 2 \mathrm{Fwww}$.google.com $\% 2 \mathrm{~F}$.

Lorenz, K. (1974). Das sogenannte böse. Zur naturgeschichte der aggression. Amsterdam: Ploegsma.

Natalia, E. (2016). remaja, media sosial, dan cyberbullying. Jurnal Ilmiah Komunikasi, 5 (2), 119-139.

Prabawa, A. F. (2018). Peran lingkungan membentuk generasi rahmatan lil alamin. Malang: LPI Sabilillah Malang.

Prasadana, D. (2017). Cyberbullying dalam media sosial anak smp (studi kasus pada anak smp pengguna twitter di kelurahan jatibening kecamatan pondok gede kota bekasi). Komunika, 11 (1), 141-148.

Putri, F. (2016). Opini siswa terhadap tindakan cyberbullying di media sosial (studi deskriptif opini siswa sman 1 medan terhadap tindakan cyberbully di media sosial). Jurnal Ilmu Komunikasi FLOW, 2 (18), 1-10.

Rachmatan, R. \& Ayunizar, S. (2017). Cyberbullying pada remaja sma di banda aceh. Jurnal Insight Fakultas Psikologi Universitas Muhammadiyah Jember, 13 (2), 67-79.

Rahayu, F. (2012). Cyberbullying sebagai dampak negatif penggunaan teknologi informasi. Journal of Information Systems, 8 (1), 22-31.

Ratnasari, S \& Suleeman, J. (2017). Perbedaan regulasi emosi perempuan dan lakilaki di perguruan tinggi. Jurnal Psikologi Sosial, 15 (1), 35-46.

Rizki, B. (2015). Pengaruh kontrol diri, iklim sekolah, dan jenis kelamin terhadap perilaku cyberbullying pada remaja. Skripsi. Jakarta: Universitas Islam Negeri Syarif Hidayatullah.

Shofy, M., Rochani, S., \& Pranawa, S. (2017). Cyberbullying di kalangan peserta didik (studi etnometodologi di kalangan peserta didik sma 2 kota surakarta). Sosialitas: Jurnal Ilmiah Pendidikan Sosiologi Antropologi, 8 (1), 1-15.

Simon, R. W., dan Nath, L. E. (2004) Gender and emotion in the united states: do men and women differ in self-reports of feelings and expressive behavior?. American Journal of Sociology, 109 (5), 1137-1176. Doi: 10.1086/382111.

Slonje, R., \& Smith, P. (2008). Cyberbulling: another main type of bullying. Scandinavian Journal of Psychology, 2008 (49), 147-154. doi: 10.1111/j.14679450.2007.00611.x. 
Willard, N. (2005). Educator's guide to cyberbullying addressing the harm caused by outline social cruelty. Retrieved from http://www.asdk12.org/MiddleLink/AVB/bully_topics/EducatorsGuideCyberbull ying.pdf.

Ybarra, M. \& Mitchell, K. (2004). Youth engaging in online harassment: associations with caregiver-child relationships, internet use, and personal characteristics. Journal of Adolescence, 2014 (27), 319-336. doi: 10.1016/j.adolescence.2004.03.007.

Zalaquett, C. \& Chatters, S. (2014). Cyberbullying in college: frequency, characteristics, and pracical implications. Sage Open, 2014 (1), 1-8. doi: 10.1177/2158244014526721. 